\title{
Knowledge, attitude and practice of over-the- counter drug among medical and dental students-a cross sectional study
}

\author{
Bindu Malla*1, Deepti KC²
}

'Department of Pharmacy, ${ }^{2}$ Department of Nursing, Gandaki Medical College Teaching Hospital, Pokhara, Nepal

\begin{abstract}
Introduction: Self-medication of the over-the-counter drug is practiced all over the world to address minor illness. But this practice can promote irrational use of medicine; prolong the illness, drug dependency and abuse. Medical students are the future medical practitioners and play the crucial role in treatment and counseling the patients regarding the appropriate use of medicines. Therefore, the present study was conducted to assess the knowledge, attitude and practice of self- medication of over-the-counter drugs among undergraduate students. Methods: An institution based descriptive, cross-sectional study was conducted after taking ethical approval from the Institutional review committee of Gandaki medical college teaching hospital and research center (GMCTHRC) and data was collected from May to July 2018 from MBBS (90) and BDS (25) first year students. Descriptive and correlation analysis were done with the data. The results were expressed in percentages. Results: Among 115 respondents, 70 were female and 45 were male students. Majority of respondents (94.8\%) believed that instruction on the label of the drugs should be followed and $78.3 \%$ respondents agreed that over-the-counter drugs could interact with other prescribed drugs. Majority of them agreed that clinical history should be taken before dispensing the over-the-counter drugs and pharmacists should provide information regarding the side effects, appropriate use and storage of the drugs. There was weak positive correlation between knowledge and attitude ( $r=0.288$ ) but despite good knowledge and attitude only $37.4 \%$ students had good practice. Conclusions: We concluded that the students hadn't been fully utilized their good knowledge into action.
\end{abstract}

Key words: Attitude, knowledge, medical student, OTC drugs, practice, self-medication.

\section{*Correspondence:}

Bindu Malla

Associate Professor, Department of Pharmacy Gandaki Medical College Teaching Hospital, Pokhara, Nepal

Email: bindumalla12@gmail.com

Submitted: August 14, 2021

Accepted: December 26, 2021

To cite: Malla B, KC D. Knowledge, attitude and practice of over-the-counter drug among medical and dental students-a cross sectional study. JGMC Nepal. 2021;14(2):153-9.

DOI: $10.3126 /$ jgmcn.v14i2.39336

\section{INTRODUCTION}

Over-the-counter (OTC) drugs are those drugs that can be sold directly to a consumer without a prescription from pharmacy and in Nepal OTC drugs are categorized as Group Ga drugs whereas, prescription drugs are those drugs that are dispensed only to consumer possessing a valid prescription. Lack of adequate knowledge about OTC medications may directly lead to adverse drug reactions and non-compliance to treatment programs. The evidence of self-medication practice of OTC drugs has been raised. ${ }^{1-3}$ The World Health Organization (WHO) has defined self-medication as the selection and use of medicines by individuals to treat selfrecognized illnesses or symptoms without consultation of health care professionals. ${ }^{4}$

Self-medication is an important component of self health care system and is a serious public health concern in both developed and developing countries. Self-medication may include using OTC 
drugs, leftover drugs from previous prescribed drugs and drugs obtained from relatives or friends. ${ }^{5}$ Good selfmedication practice can provide benefits such as saving scarce medical resources from being wasted on minor conditions, lowering the costs of community-funded health care programs and reducing absenteeism from work due to minor symptoms. ${ }^{6}$ Pharmacists can play a key role in giving advice to consumers on the proper and safe use of medicinal products intended for self-medication. On the contrary, risk associated with self-medications include incorrect self-diagnosis, failure to seek appropriate medical advice promptly, incorrect choice of therapy, failure to recognize special pharmacological risks, rare but severe adverse effects, failure to recognize contraindications, warnings and precautions, masking of symptom of the serious, increase poly-pharmacy and interaction with other regularly used medication. ${ }^{2,7-9}$

Globally, the self-medication of OTC drugs among medical students is a common practice. ${ }^{10-12}$ For instance a crosssectional study conducted in medical students at Punjab, India showed that the prevalence of self-medication increased with the increase in the year of study due to increase in knowledge of medicines. The study also revealed that the most commonly used medicines were antipyretics and analgesics. ${ }^{11}$ Similar studies conducted in Rajarajeswari Medical College, Bangalore, India, College of Medicine-Nepalese Army Institute of Health Sciences, Kathmandu and University of Gondar, Northwest Ethiopia showed that the prevalence of self-medication was $86 \%$, $76.6 \%$ and $59.7 \%$ respectively, in the medical students. ${ }^{12-14}$

Young medical students are among the most vulnerable to self-medication because of their higher educational level and ability to find information about medications through the Internet. Beside this, the other reasons for the practice of self-medication are like: suffering from a mild illness, having previous experience in treating similar illnesses, economic, advertising of drug manufacturers, excessive accessibility and availability of OTC medications. ${ }^{10,11,15}$ They are the future medical practitioners and play the crucial role in treatment and counseling their patients about the advantages and disadvantages of self-medication of OTC drugs. Therefore, they must be aware about the irrational and inappropriate usage of OTC drugs might be more harmful than useful to the patients. However, limited data are available on health care facilities, comprising the knowledge, attitude and practice of self-medication of OTC drugs among freshman students in Nepal. Hence, this study aimed to assess the knowledge, attitude and practice of first year medical and dental students towards the self- medication of OTC drugs.

\section{METHODS}

Study design, setting and population: An institution based descriptive cross-sectional study design was conducted to assess the knowledge, attitude and practice (KAP) on self-medication of OTC drugs among first year MBBS and BDS undergraduate students of Gandaki medical college teaching hospital and research center (GMCTHRC).

Inclusion Criteria: Students who were studying in the MBBS and BDS first year were included in the study.

Sample size and sampling technique: A total of 115 students were present in the first year MBBS and BDS and census method was applied to collect the data from the respondents.

Data collection tool and techniques: It was structured and non-interventional questionnaire study. A structured questionnaire was prepared after reviewing the validated questionnaire from relevant studies with few modifications ${ }_{3,12,15,16}$ which was distributed among students after briefing about the purpose of the study and instruction to fill the questionnaire. The anonymity of subjects was maintained by asking them not to write their name and students were not forced to participate during the study period. An adequate time was given to fill up the questionnaire and the filled questionnaires were collected after completion. The questionnaire was divided into 4 parts: part 1 of the questionnaire included demographic characteristics of the students: age, gender, and department. Part 2 of the questionnaire assessed the participant's knowledge by using a set of eight yes and no questions and a score of equal to or below the median knowledge cumulative score of 8 demonstrated bad knowledge and a score above the median knowledge cumulative score of 8 indicated good knowledge. Part 3 of the questionnaire assessed the participant's attitude about self medication by using a set of three yes and no questions and a score above the median cumulative attitude score of 3 demonstrated negative attitudes and a score above the median cumulative attitude score of 3 indicated positive attitude. Part 4 of the questionnaire assessed the practice towards selfmedication to the students by using a set of four yes and no questions and a score equal to or below the median cumulative practice score of 4 demonstrated bad practice and a score above the median cumulative practice score of 4 indicated good practice. Apart from these questions there are three more questions which assessed the most common source of drugs for self- medication, purchase of 
drugs for self- medication by using brand name or generic name and the most common drugs for the self-medication. The performance was assessed by scores $0=$ wrong response and 1 = correct response). ${ }^{17}$

Data analysis: The survey was descriptive and the collected data were entered into Microsoft excel 2007 results were analyzed using Statistical Package for Social Science (SPSS) version 21.0. All qualitative variables were presented using descriptive statistics with frequency and percentages. Chi-square analysis was conducted to compare the KAP of MBBS and dental students. A P-value of $<0.05$ was taken to declare statistical significance.

Ethical Considerations: Ethical approval was obtained from the Institutional review committee of the GMCTHRC (Reference number 06-11-2074). Informed consent was also obtained from each respondent after explaining the purpose of the study. Participant's confidentiality was guaranteed by collecting the data anonymously. The data was collected from first week of May to last week of July 2018.

\section{RESULTS}

Table 1 presents the socio-demographic characteristics of the respondents. Nearly half of the students (46.1\%) were 19 years of age. All of them were single. More than half $(60.9 \%)$ of the respondents were female. Majority of respondents (78.3\%) were from MBBS background.

Table 1: Socio-demographic characteristics of respondents $(n=115)$

\begin{tabular}{lcc}
\hline Characteristics & Number & Percentage \\
Age (in years) & & \\
18 & 23 & 20.0 \\
19 & 53 & 46.1 \\
20 & 36 & 31.3 \\
21 & 3 & 2.6 \\
Mean age \pm SD $=19.16 \pm 0.775$ & & \\
Gender & & \\
$\quad$ Female & 70 & 60.9 \\
$\quad$ Male & 45 & 39.1 \\
$\quad$ Department & & \\
$\quad$ MBBS & & 78.3 \\
BDS & 90 & 21.7 \\
\hline
\end{tabular}

Table 2 shows the knowledge of students towards selfmedication of OTC drugs. Among 115 students, 35.7\% believed that OTC drugs are safe drugs to consume. Majority of them agreed that continue use of OTC drugs leads to the adverse effects and drug dependency. Though most of them were correct about the proper use of OTC drugs but only $78.3 \%$ students were aware regarding the drug- drug interaction caused by OTC drugs with the prescription drugs. Most of them (94.8\%) agreed that the instruction on the label of the drug should be followed. Only 53.9\% students knew that OTC drugs are categorized as group Ga drugs in Nepal. Similarly, only $66.9 \%$ students knew that prescription only drugs are categorized as group Ka and Kha in Nepal. ${ }^{18}$

Table 2: Knowledge of students towards self-medication of OTC drugs $(n=115)$

\begin{tabular}{|c|c|c|c|c|c|c|}
\hline \multirow[t]{2}{*}{ Characteristics } & & $\begin{array}{l}\text { MBBS } \\
(n=90)\end{array}$ & $\begin{array}{c}\text { BDS } \\
(n=25)\end{array}$ & $\begin{array}{c}\text { Total } \\
\text { Mean (SD): } \\
6.130(1.246)\end{array}$ & \multirow[t]{2}{*}{ Chi-square } & \multirow[t]{2}{*}{ P-value } \\
\hline & & $\begin{array}{c}\text { Frequency } \\
(\%)\end{array}$ & $\begin{array}{c}\text { Frequency } \\
(\%)\end{array}$ & $\begin{array}{c}\text { Frequency } \\
\text { (\%) }\end{array}$ & & \\
\hline $\begin{array}{l}\text { K1. Are OTC drug } \\
\text { safe to consume? }\end{array}$ & $\begin{array}{l}\text { Yes* } \\
\text { No }\end{array}$ & $\begin{array}{l}32(35.5) \\
58(64.5)\end{array}$ & $\begin{array}{l}9(36) \\
16(64)\end{array}$ & $\begin{array}{l}41(35.7) \\
74(64.3)\end{array}$ & 0.002 & 0.967 \\
\hline $\begin{array}{l}\text { K2. Do continuous } \\
\text { use of OTC drugs } \\
\text { results in adverse } \\
\text { effects? }\end{array}$ & $\begin{array}{l}\text { Yes* } \\
\text { No }\end{array}$ & $\begin{array}{c}87(96.6) \\
3(3.4)\end{array}$ & $\begin{array}{c}25(100.0) \\
0(0)\end{array}$ & $\begin{array}{c}112(97.4) \\
3(2.6)\end{array}$ & 0.856 & 0.355 \\
\hline $\begin{array}{l}\text { K3. Continuous } \\
\text { use of OTC drugs } \\
\text { may results in } \\
\text { dependency. }\end{array}$ & $\begin{array}{l}\text { Yes* } \\
\text { No }\end{array}$ & $\begin{array}{c}85(94.4) \\
5(5.6)\end{array}$ & $\begin{array}{c}25(100.0) \\
0(0)\end{array}$ & $\begin{array}{c}110(95.7) \\
5(4.3)\end{array}$ & 1.452 & 0.228 \\
\hline $\begin{array}{l}\text { K4. OTC drug should } \\
\text { be taken according to } \\
\text { recommended dose. }\end{array}$ & $\begin{array}{l}\text { Yes* } \\
\text { No }\end{array}$ & $\begin{array}{c}82(91.1) \\
8(8.9)\end{array}$ & $\begin{array}{c}22(88.0) \\
3(12)\end{array}$ & $\begin{array}{c}104(90.4) \\
11(9.6)\end{array}$ & 0.219 & 0.640 \\
\hline $\begin{array}{l}\text { K5. The instruction } \\
\text { on the label of } \\
\text { OTC drug must be } \\
\text { followed. }\end{array}$ & $\begin{array}{l}\text { Yes* } \\
\text { No }\end{array}$ & $\begin{array}{c}85(94.4) \\
5(5.6)\end{array}$ & $\begin{array}{c}24(96.0) \\
1(4)\end{array}$ & $\begin{array}{c}109(94.8) \\
6(5.2)\end{array}$ & 0.096 & 0.757 \\
\hline $\begin{array}{l}\text { K6. OTC drug could } \\
\text { interact with other } \\
\text { prescribed drugs. }\end{array}$ & $\begin{array}{l}\text { Yes* } \\
\text { No }\end{array}$ & $\begin{array}{l}70(77.7) \\
20(22.3)\end{array}$ & $\begin{array}{c}20(80.0) \\
5\end{array}$ & $\begin{array}{c}90(78.3) \\
25\end{array}$ & 0.57 & 0.812 \\
\hline $\begin{array}{l}\text { K7. Group Ga are } \\
\text { only the OTC drug in } \\
\text { Nepal. }\end{array}$ & $\begin{array}{l}\text { Yes* } \\
\text { No }\end{array}$ & $\begin{array}{l}48(53.3) \\
42(46.7)\end{array}$ & $\begin{array}{l}14(56) \\
11(44)\end{array}$ & $\begin{array}{l}62(53.9) \\
53(46.1)\end{array}$ & 0.56 & 0.813 \\
\hline $\begin{array}{l}\text { K8. Group Ka and Kha } \\
\text { are the prescription } \\
\text { drugs in Nepal. }\end{array}$ & $\begin{array}{l}\text { Yes* } \\
\text { No }\end{array}$ & $\begin{array}{l}62(68.8) \\
28(31.2)\end{array}$ & $\begin{array}{l}15(60) \\
10(40)\end{array}$ & $\begin{array}{l}77(66.9) \\
38(33.1)\end{array}$ & 0.699 & 0.403 \\
\hline
\end{tabular}

\section{*Correct response}

Table 3 reveals the attitude and practice of students towards self-medication of OTC drugs.Majority of them (99.1\%) agreed that pharmacist must be aware about the possible side effect of the drugs and should provide the appropriate information regarding the rational use of the drugs while dispensing. But before dispensing the drugs proper clinical history and medication history should be taken. Only $82.6 \%$ students were correct in this aspect. 
Out of 115 students only $37.4 \%$ students knew about the correct dose and $46 \%$ students knew the correct frequency and duration of the drugs. Those who did not get relief from the OTC drugs (11.3\%) mention that they went to the hospital for the further treatment. Moreover, majority of them bought the drugs by brand name for self-medication from the retail pharmacy and antipyretics (48.7\%) was the most commonly used OTC drug for self-medication.

Table 3: Attitude and Practice of students towards selfmedication of OTC drugs.

\begin{tabular}{|c|c|c|c|c|c|c|}
\hline Attitude related questi & ions & $\begin{array}{l}\text { Frequency } \\
(\%)\end{array}$ & $\begin{array}{c}\begin{array}{c}\text { BDS } \\
(\mathrm{n}=25)\end{array} \\
\text { Frequency } \\
(\%)\end{array}$ & $\begin{array}{c}\text { Total } \\
\text { Mean (SD): } \\
2.808(0.456) \\
\text { Frequency } \\
\text { (\%) }\end{array}$ & $\begin{array}{l}\text { Chi- } \\
\text { square }\end{array}$ & P-value \\
\hline $\begin{array}{l}\text { A1. Clinical history should } \\
\text { be taken before } \\
\text { dispensing the 0TC drugs. }\end{array}$ & $\begin{array}{l}\text { Yes* } \\
\text { No }\end{array}$ & $\begin{array}{l}73(81.1) \\
17(18.9)\end{array}$ & $\begin{array}{l}22(88.0) \\
3(12)\end{array}$ & $\begin{array}{l}95(82.6) \\
20(17.4)\end{array}$ & 0.646 & 0.421 \\
\hline $\begin{array}{l}\text { A2. Pharmacist should } \\
\text { aware the possible side } \\
\text { effects of the drugs. }\end{array}$ & $\begin{array}{l}\text { Yes* } \\
\text { No }\end{array}$ & $\begin{array}{c}89(98.8) \\
1(1.2)\end{array}$ & $\begin{array}{c}25(100.0) \\
0(0.0)\end{array}$ & $\begin{array}{l}114(99.1) \\
1(0.9)\end{array}$ & 0.280 & 0.597 \\
\hline $\begin{array}{l}\text { A3. Pharmacist should } \\
\text { provide the information } \\
\text { of the drug. }\end{array}$ & $\begin{array}{l}\text { Yes* } \\
\text { No }\end{array}$ & $\begin{array}{c}89(98.8) \\
1(1.2)\end{array}$ & $\begin{array}{c}25(100.0) \\
0(0.0)\end{array}$ & $\begin{array}{l}114(99.1) \\
1(0.9)\end{array}$ & 0.280 & 0.597 \\
\hline $\begin{array}{l}\text { Practice related } \\
\text { questions }\end{array}$ & & & & $\begin{array}{l}\text { Mean (SD): } \\
2.026(1.029)\end{array}$ & & \\
\hline $\begin{array}{l}\text { P1. Did you know the } \\
\text { correct dose of a drug? }\end{array}$ & $\begin{array}{l}\text { Yes* } \\
\text { No }\end{array}$ & $\begin{array}{c}33(36.6) \\
57(63.4)\end{array}$ & $\begin{array}{l}10(40) \\
15(60)\end{array}$ & $\begin{array}{l}43(37.4) \\
72(62.6)\end{array}$ & 0.093 & 0.761 \\
\hline $\begin{array}{l}\text { P2. Did you know correct } \\
\text { frequency and duration } \\
\text { of a drug? }\end{array}$ & $\begin{array}{l}\text { Yes* } \\
\text { No }\end{array}$ & $\begin{array}{l}41(45.5) \\
49(54.5)\end{array}$ & $\begin{array}{l}12(48) \\
13(52)\end{array}$ & $\begin{array}{l}53(46.0) \\
62(54)\end{array}$ & 0.47 & 0.828 \\
\hline $\begin{array}{l}\text { P3. Did you ever combine } \\
\text { two or more medicine as } \\
\text { per instruction? }\end{array}$ & $\begin{array}{l}\text { Yes* } \\
\text { No }\end{array}$ & $\begin{array}{c}26(28.8) \\
64\end{array}$ & $\begin{array}{c}9(36) \\
16(64)\end{array}$ & $\begin{array}{l}35(30.4) \\
80(69.6)\end{array}$ & 0.467 & 0.494 \\
\hline P4. Have you got relief? & $\begin{array}{l}\text { Yes* } \\
\text { No }\end{array}$ & $\begin{array}{l}79(87.7) \\
11(12.3)\end{array}$ & $\begin{array}{c}23(92) \\
2(8)\end{array}$ & $\begin{array}{c}102(88.7) \\
13(11.4)\end{array}$ & 0.348 & 0.555 \\
\hline $\begin{array}{l}\text { The most common } \\
\text { source of drug for self } \\
\text { medication. }\end{array}$ & $\begin{array}{c}\text { Retail } \\
\text { Pharmacy } \\
\text { Family and } \\
\text { friends }\end{array}$ & $85(94.4)$ & $24(96)$ & $\begin{array}{c}109(94.8) \\
6(5.2)\end{array}$ & - & - \\
\hline $\begin{array}{l}\text { Drugs are purchased } \\
\text { from the pharmacy } \\
\text { by: }\end{array}$ & $\begin{array}{l}\text { Brand } \\
\text { name } \\
\text { Generic } \\
\text { name }\end{array}$ & $\begin{array}{l}70(77.77) \\
20(22.23)\end{array}$ & $\begin{array}{l}14(56) \\
11(44)\end{array}$ & $\begin{array}{l}84(73.04) \\
31(26.96)\end{array}$ & - & - \\
\hline $\begin{array}{l}\text { The most commonly } \\
\text { used OTC drugs for } \\
\text { self-medication - }\end{array}$ & $\begin{array}{l}\text { Antipyretic } \\
\text { Analgesic } \\
\text { Cold and } \\
\text { cough } \\
\text { Vitamins }\end{array}$ & $\begin{array}{c}45(50) \\
30(33.3) \\
10(11.1) \\
5(5.6)\end{array}$ & $\begin{array}{l}11(44) \\
6(24) \\
5(20) \\
3(12)\end{array}$ & $\begin{array}{c}56(48.70) \\
36(31.30) \\
15(13.04) \\
8(6.960\end{array}$ & - & - \\
\hline
\end{tabular}

\section{*Correct response}

Table 4 depicts the level of Knowledge, attitude and practice of the respondents. Majority of them (90.4\%) have good knowledge and positive attitude (99.1\%) regarding the self medication of OTC drugs. Despite good knowledge and attitude only $37.4 \%$ students had good practice in the rational use of the OTC drugs.
Table 4: Respondents' Level of knowledge, attitude and practice $(n=115)$



*Note:-Poor Knowledge ( $\leq 50 \%)$, Good Knowledge (>50\%), Negative Attitude ( $\leq 50 \%)$, Positive Attitude (>50\%), Poor practice $(\leq 50 \%)$, Good practice $(>50 \%) .{ }^{17}$

Table 5 shows the correlation between knowledge, attitude and practice using Pearson Correlation Test. Knowledge had significant fair positive correlation with attitude $(\mathrm{r}=0.228 ; \mathrm{p}<0.001)$ and no correlation with practice $(\mathrm{r}=0.129 ; \mathrm{p}=0.085)$. In addition, there was no significant correlation between attitude and practice $(\mathrm{r}=0.072$; $\mathrm{p}=0.221$ ).

Table 5: Correlation between knowledge, attitude and practice using Pearson Correlation Test

\begin{tabular}{lcc}
\hline Variables & r-value & P-value \\
Knowledge and Practice & 0.129 & 0.085 \\
Knowledge and Attitude & $0.288^{*}$ & 0.001 \\
Attitude and Practice & 0.072 & 0.221 \\
\hline
\end{tabular}

*Correlation is significant at the level of 0.001 .

\section{DISCUSSION}

In the current study, there were 115 students which comprised of $39.1 \%$ males and $60.9 \%$ females. Out of 115 medical and dental students, the prevalence of the practice of self-medication within 6 months was 53 (46.08\%). This suggests that self-medication is quite prevalent among them. Similar study conducted in India also reported $45.6 \%$ of first year medical students used OTC drugs as it is time saving. ${ }^{12}$ In agreement to our findings, high prevalence of self-medication practice among undergraduate have been documented by numerous studies. ${ }^{19,20-23}$ 
Among them, $35.7 \%$ students believed that OTC drugs are safe drugs to consume. The rational use of OTC drugs should be promoted because OTC drugs are believed to be safe and effective, indeed they are not. ${ }^{24}$ When adopted effectively the self-medication practice can be beneficial because it may relieve acute pain, reduce treatment cost and physician interaction time. However, when used inappropriately they can cause severe health related complication such as masking the underlying disease and causing several adverse effects. Inappropriate and frequent use of OTC drugs can lead to the inappropriate dosing, drug duplication, drug interaction and treatment failure. ${ }^{17,25}$ Doctors and pharmacists play a crucial role in increasing awareness about self-medication by educating the patients. Majority of them (99.1\%) agreed that pharmacist should take the clinical history, keep the patients' medication record and provide the drug information while dispensing the OTC drugs. There was no significant difference identified among the medical and dental students concerning the knowledge, attitude and practice towards self-medication of OTC drugs.

In the current study, the mean knowledge score was 6.13. This finding was consistent with a study conducted in Ethiopia which reported that more than half of the respondents were found to have good knowledge about self-medication of OTC drugs and had a positive attitude. ${ }^{17}$

This study found that the most common source of drugs for self-medication was pharmacy (94.4\%), and this is in accordance with previous study conducted in Nepal. ${ }^{19,20}$ Majority of them (77.77 \%) purchased drugs from pharmacy by brand name. Antipyretics, analgesic, drugs used in cold and cough and vitamins were the drugs used for the self-medication by the study participants. Among them antipyretic drugs (48.70\%) were the most commonly used drug for self-medication. This finding was also consistent with findings from previous studies conducted in Addis Ababa, West Bengal, Jammu and Kashmir, Eritrea in which antipyretic and analgesic medications were the most frequently used OTC medications. ${ }^{25-28}$ Due to stress and other educational loads, medical students were usually victims of headaches and fever that usually force them to administer antipyretic and analgesic medications. ${ }^{29}$ These students have easy access to information from medical books, internet search, senior medical students and pharmacy, so they irrationally use drugs more commonly than general population. ${ }^{25}$ Though $94.8 \%$ participants cited that the instruction on the label of OTC drug must be followed and this can be the source of information as well but more than half participants did not know the correct dose, frequency and duration of the OTC drugs for selfmedication. Moreover, $30.4 \%$ of them combine the OTC drugs for better therapeutic outcomes.

According to WHO (May 2010) more than 50\% of all medicines are not correctly prescribed, dispensed, and sold; and more than $50 \%$ of patients take their drugs incorrectly in the developing countries. In addition to this, virtually all the drugs are available here without prescriptions and selfmedication are highly common. ${ }^{30}$ In agreement to a fact sheet of the WHO in our study also more than $50 \%$ of the students had bad practice and incorrect use of the drugs.

Our study showed that there was weak positive correlation between the knowledge and the attitude regarding the self-medication of OTC drugs. Indeed, $90.4 \%$ students had good knowledge and because of this almost all the students $(99.1 \%)$ had positive attitude $(\mathrm{p}<0.001)$ towards the selfmedication of OTC drugs. They have positive attitude with good theoretical knowledge however, good practice was less $(37.4 \%)$. So, this study strongly recommends them to use their theoretical knowledge into practice.

\section{CONCLUSIONS}

In this study we concluded that majority of first year medical and dental students had good knowledge and positive attitude towards the OTC drugs but they were not clear about the correct dose, frequency and duration of the drugs. This showed that the knowledge hadn't been fully practiced into action. Therefore, awareness program regarding the patient medication safety should be provided to the students for improving the correct practice of OTC medicines.

\section{LIMITATION OF THE STUDY}

Our study had limitations. The limitation of this study included that the study involved lesser number of students and only from first year of a single institute which might not be the representation for all medical students. The limitation could be concerning the study participants, in which the study could have been more applicable if other health professional students and/or students from the whole years of study (1st year to final year) were included. Other limitation is that such type of study should be conducted in the community as well because OTC drugs are commonly used by the public.

\section{ACKNOWLEDGEMENT}

The authors of this research would like to acknowledge the 
study participants, GMCTHRC and facilitators.

SOURCE OF FUNDING: No funding sources

CONFLICT OF INTEREST: None declared

\section{REFERENCES}

1. Eissa AT. Knowledge, attitudes and practices towards medication use among health care students in King Saud University. Int J Med Students. 2013;1(2):66-9. DOI: $10.5195 /$ ijms.2013.205

2. Dilie A, Gualu T, Haile D, Zuleta FA. Knowledge, attitude and practice of self-medication among health science students at Debre Markos University, Northwest Ethiopia. J. Public Health Epidemiol. 2017;9(5):10613. DOI: $10.5897 / J P H E 2017.0926$.

3. Sharma D, Gurung D, Kafle R, Singh S. Knowledge and practice on over-the-counter drugs among adults of age group 20 and above residing in Chapapani-12, Pokhara, Kaski, Nepal. Int J Sci Rep. 2017;3(3):79-86. DOI: 10.18203/issn.2454-2156.IntJSciRep20170887

4. Jha N, Bajracharya O, Shankar PR. Knowledge, attitude and practice towards medicines among school teachers in Lalitpur district, Nepal before and after an educational intervention. BMC Public Health. 2013;13:652. DOI: 10.1186/1471-2458-13-652 PMID: 23849402.

5. Alves RF, Precioso J, Becona E. Knowledge, attitudes and practice of self-medication among university students in Portugal: A cross-sectional study Nordic Studies on Alcohol and Drugs. 2021;38(1):50-65. DOI: $10.1177 / 1455072520965017$

6. Thadani S, Salman MT, Ahmad A. Knowledge, Attitude and Practice of Self Medication among Second Year Undergraduate Medical Students. J Rational Pharmacother Res. 2013;1(3):131-34

7. Guidelines for the regulatory assessment of medicinal products for use in Self medication, WHO 2000. Available from: http:/aap.who.int/medicine docs/pdf. [Accessed on 10 ${ }^{\text {th }}$ May, 2018].

8. Angamo NT and Wabe NT. Knowledge, attitude and practice of self medication in southwest Ethopia. IJPSR. 2012;3(4):1005-10.

9. Karmacharya A, Uprety BN, Pathiyil RS, Gyawali S. Knowledge and practice of self-medication among undergraduate medical students. J. Lumbini. Med.
2018;6(1):21-6.

10. Behzadifar M, Behzadifar M, Aryankhesal A, Ravaghi H, Baradaran HR, Sajadi HS. et al. Prevalence of self-medication in university students: systematic review and meta-analysis.East Mediterr Health J. 2020;26(7):846-57. DOI: 10.26719/emhj.20.052 PMID: 32794171.

11. Mannat KB, Singh R, Singh A, Bhardwaj BL. Knowledge, attitude and practice of self medication among undergraduate medical students of Punjab. JMR 2017;3(3):151-54.

12. Subramanian S, Satyanarayana V, Bhandare B. A study on knowledge and practices of over the counter medications among 1st year medical students. Int J Basic Clin Pharmacol. 2018;7:2452-5.

13. Khadka A, Kafle KK. Prevalence of Self-medication among MBBS Students of a Medical College in Kathmandu. J Nepal Med Assoc. 2020;58(222):69-75. DOI: $10.31729 /$ jnma.4674

14. Tesfaye ZT, Ergena AE, and Yimer BT. Self-Medication among Medical and Nonmedical Students at the University of Gondar, Northwest Ethiopia: A Cross-Sectional Study. Scientifica. 2020. DOI: 10.1155/2020/4021586 PMID: 32676214.

15. Goya A, Gaur A, Singh M, Ranjan R, Deepak K. Knowledge attitude and practices of over the counter (OTC)medicines among urban population-a cross sectional study. Ind Res J Pharm \& Sci. 2018;5(1):130209.

16. Khalil N. Medical Students' Knowledge and Attitudes towards Self-Medication in AlIraqia University, Baghdad, Iraq. Br J Med Med Res. 2016;12(8):1-9.

17. Bekele KM, Abay AM, Mengistu KA, Atsbeha BW, Demeke CA, Belay WS et al. Knowledge, attitude, and practice on over-the-counter drugs among pharmacy and medical students: A facility-based cross-sectional study. Integr Pharm Res Pract. 2020;9: 135-4 DOI: 10.4103/jrpp.JRPP_20_98 PMID: 33489981.

18. Classification of drugs in Nepal. Available from: https://pharmainfonepal.com/classification-ofdrugs-in-nepal/ [Accessed on $1^{\text {st }}$ December 2021]. DOI: $10.31729 /$ jnma.4674

19. Shrestha JTM, Kushwaha DK, Tewari S. Study of self-medication among first and senventh semester 
medical and Dental undergraduate students of tertiary care teaching hospital in Nepal. A descriptive crosssectional study. J Nepal Med Assoc. 2021; 59(233):5560.

20. Khadka A, Kafle KK. Prevalence of Self-medication among MBBS Students of a Medical College in Kathmandu. J Nepal Med Assoc. 2020;58(222):69-75.

21. Beyene A, Getachew E, Doboch A, Poulos E, Abdurahman K. Knowledge, attitude and practice of self-medication among pharmacy students of rift Valley University, Abichu campus, Addis Ababa, Ethiopia. J Health Med Informat. 2017;8(269):2. DOI: 10.4172/2157- 7420.1000269

22. Baral K, Dahal M, Shrestha S, Adhikari A. Selfmedication: Prevalence among undergraduates in Kathmandu valley. JAMPS. 2019;21(1):1-13.

23. Gyawali S, Shankar PR, Poudel PP, Saha A. Knowledge, attitude and practice of self-Medication among basic science undergraduate medical students in a medical school in western Nepal. Journal of Clinical and Diagnostic Research. 2015; 9(12):17-22. DOI: 10.1016/j.frl.2014.12.004

24. Tesfamariam S, Anand IS, Kaleab G, Berhane S, Woldai $B$, Habte E et al. Self-medication with over the counter drugs, prevalence of risky practice and its associated factors in pharmacy outlets of Asmara, Eritrea. BMC Public Health. 2019;19:159. DOI: 10.1186/s12889019-6470-5
25. Bhattarai AK, Karki PK. Knowledge, attitude and practice of self-medication among medical students during exam time. Journal of Chitwan Medical College. 2020;10(33):25-8.

26. Ghosh A, Biswas S, Mondal K, Haldar M, Biswas S. A Study on Knowledge and Practices of over the counter medications among $2^{\text {nd }}$ year medical students. World J Pharma Pharmaceu Sci. 2015;4(7):1074-81.

27. Banerjee I, Sathian B, Gupta RK, Amarendra A, Roy B, Bakthavatchalam P, Saha A, Banerjee I. Self-medication practice among preclinical university students in a medical school from the city of Pokhara, Nepal. Nepal J Epidemiol. 2016;6(2):574-581.

28. Tesfamariam S, Anand IS, Kaleab G, Berhane S, WoldaiB,HabteE,Russom M. Self-medication with over the counter drugs, prevalence of risky practice and its associated factors in pharmacy outlets of Asmara, Eritrea. BMC Public Health. 2019;19:159. DOI: $10.1186 / s 12889-019-6470-5$

29. Gupta S, Khajuria K, Bhat NK, Khajuria V, Mehra A. Assessment of the knowledge, attitude and practice of self medication among second year undergraduate medical students in a tertiary care teaching hospital. Int J Basic Clin Pharmacol. 2019;8:1090-5.

30. Shah K, Halder S, Haider SS. Healthcare Pvt. Ltd., Chhatapipra, Bara, Nepal. Heliyon. 2021; 7. DOI: 10.1016/j.heliyon.2021.e05976. PMID: 33511295. 